\title{
The role of financial knowledge in realizing financial behavior: is it any mediating effect of financial attitudes and self-efficacy?
}

\author{
Ardiana Nur Maulida H, Indarto, Aprih Santoso* \\ Department of Management, Faculty of Economics, Universitas Semarang, Semarang, Indonesia
}

\author{
Article History \\ Received : 10 June 2021 \\ Revised : 22 August 2021 \\ Accepted : 26 August 2021 \\ Published : 27 August 2021
}

Keywords:

Knowledge, attitude, finance, self efficacy, behavior

*Corresponding author: aprihsantoso@usm.ac.id

DOI:

10.20885/AMBR.vol1.iss2.art5

\begin{abstract}
The purpose of the study was to analyze the effect of financial knowledge on financial behavior with financial attitudes and selfefficacy as mediating variables. The population of this research is that all students in Semarang are unknown. The number of respondents to 96 people. The sample selection method is purposive sampling, namely: students have taken courses in financial management and intermediate financial accounting and the analytical tool used in this study was Warp PLS version 5.0. The results showed that financial knowledge has a positive and significant direct effect on financial attitudes, self-efficacy and financial behavior of students in Semarang City, so that the proposed hypothesis can be accepted. Financial attitudes and self-efficacy have a positive and significant direct effect on the financial behavior of students in Semarang City, so that the proposed hypothesis can be accepted. Financial attitudes and selfefficacy do not mediate the effect of financial knowledge on financial behavior of students in Semarang City.
\end{abstract}

\section{Introduction}

The globalization era which brings improvement and economic growth to all countries in the world, including Indonesia has an impact on the financial behavior of the Indonesian people in meeting their needs. The development of the times and technological advances will indirectly affect the mindset of humans and make an individual will tend to want to update his appearance in accordance with the trends that are developing in society. The impact of this behavior will lead to consumptive behavior that is not in line with their financial condition.

Global trends anticipate that the relationship between individuals and the financial system will improve. Factors such as increasing life expectancy and changing prosperity of the country are pushing more and more individuals to be involved in making financial decisions. Decisions such as saving for retirement, spending on education and health, or buying a home, are taken in scenarios where financial markets are more accessible to consumers, due to major technological advances (reduction of transaction costs between supply and demand) and the new appearance of financial services.

Young people have to operate in an increasingly complex world of finance, especially those living in developed countries. Given their prominent spending capacity, young people are attractive targets, especially for banking and credit card institutions. However, they have limited ability to make correct financial decisions. Financial education among young people and their preparation for decision-making in their future lives has raised government concerns.

Students as agents of change become individuals who are closer to digital information technology, where they are able to apply all activities at one time using the information technology. This condition makes students able to absorb information to support existing activities, but this condition creates a problem where students are possible to become more consumptive individuals in spending their money (Novitasani \& Handoyono, 2014). Therefore, to prevent excessive consumerism in students, financial literacy is needed in students so that they are able to control 
their finances wisely so that consumerism patterns do not become a problem for students in the future (Lusardi \& Mitchell, 2013).

The Organization for Economic Co-operation and Development (OECD, 2012) conceptualizes financial literacy as a complex phenomenon consisting of a combination of awareness, knowledge, abilities, attitudes, and behaviors needed to make financial decisions. Financial literacy is the capacity to use the knowledge and abilities acquired from the individual. In other words, the focus of financial knowledge is individual knowledge related to aspects of financial management, while financial literacy involves individual financial knowledge, behavior, and attitudes (Potrich et al., 2016). Financial literacy reflects an individual's ability to understand financial information and use it skillfully and confidently to use it from a multi-dimensional perspective in conceptualizing and operationalizing existing constructs (Huston, 2010).

Huang et al. (2013) consider financial knowledge as an understanding of individual financial concepts. Financial knowledge is a special type of capital acquired in life through the ability to learn to manage income, expenses and savings in a safe manner (Adeline et al., 2008). Based on this definition, financial knowledge is knowledge possessed by individuals related to their financial situation, so they are able to make decisions based on existing financial conditions.

Tang and Baker (2016), Potrich et al. (2016) and Ramalho and Forte (2018) state that financial knowledge has a positive effect on individual financial behavior. In his research, he concluded that financial knowledge possessed by individuals will selectively shape individual decisions related to financial problems, so that individual financial behavior is based on financial knowledge possessed.

Based on the theory of planned behavior, behavior is an observable action that describes how individuals act under certain conditions (Schmeiser \& Seligman, 2013). Therefore, in a financial literacy study, it is important to evaluate individual decision-making processes, as well as investigate the possibility of positive individual behaviors related to their finances that can result in increased resilience in times of crisis POECD, 2012). In addition, financial literacy can understand individual financial behavior to encourage financial well-being Huston (2010); OECD (2012)) and individual behavior in greater financial satisfaction (Grable \& Joo, 2004).

Financial behavior includes behavior that uses money in the form of cash, credit, and savings (Xiao et al., 2015). Behavioral finance is based on insights from science and business to explain individual behavior as opposed to traditional financial assumptions. Puspita and Isnalita (2019), financial behavior cannot grow properly without an understanding of ideas about good financial concepts, so as to be able to deliver individuals with financial actions that are useful for their future. The financial literacy model is a model that shapes individual financial behavior, where financial behavior is influenced by financial knowledge and individual financial attitudes (Potrich et al., 2016).

Individuals who are not familiar with the concept of basic financial knowledge will find it difficult to assess so that they use financial products and services that are not based on existing knowledge (Atkinson \& Messy, 2012). Tang and Baker (2016), Potrich et al. (2016) and Ramalho and Forte (2018) contradict the research conducted by Hadar et al. (2013) which states that financial knowledge does not have to focus on objective financial knowledge, but also considers the level of subjective financial knowledge. Both objective and subjective financial knowledge should be considered in an effort to educate individuals in managing finances wisely. The inconsistency of the results of previous studies regarding the effect of financial knowledge on financial behavior indicates that there are situational variables that relate these effects. Tang and Baker (2016) show that self-efficacy is a situational variable that can link the influence of financial knowledge on financial behavior.

Bandura (1986), self-efficacy is an individual's belief about his ability to carry out a task or take an action needed to achieve a certain result. Self-efficacy refers to the belief that one can achieve and succeed at a given task accompanied by motivation, optimism and belief that one can overcome various life challenges (Bandura, 1986). Individual self-confidence is an important part of self-efficacy that encourages individuals to make a decision (Flores, 2014). Someone with high self-efficacy usually seeks challenges with tolerance for failure, and has a learning goal orientation, 
while individuals with low self-efficacy are more likely to avoid challenges, with a performance goal orientation that focuses more on achieving goals with minimal effort.

In addition to self-efficacy, attitudes towards finance are also a situational variable that relates an important role in shaping individual financial behavior. Individual attitudes towards finances are an important component in individual financial decision making. Students with good financial attitudes tend to be wiser in their financial behavior when compared to students with poor financial attitudes (Herdjiono \& Damanik, 2016). Therefore, attitudes are related to preferences that can influence behavior. Thus, financial attitudes are considered an important element of financial literacy, given that individual preferences are determinants of financial behavior (OECD, 2012).

Bad individual attitudes towards financial problems lead to undesirable consumer behavior. Individual decisions on finances based on certain emotions such as anger and anxiety will make a financial decision inappropriate. In contrast to individuals who have a high financial control attitude are more likely to have a positive attitude towards planning. The attitude of financial control is a pre-disposition to behave in a certain way which is formed due to several economic and non-economic beliefs held by individuals (Ajzen, 1991). Attitudes and preferences are treated as vital components of financial literacy (OECD, 2012).

Survey data in November 2020 of 27 students in Semarang which included 10 Semarang University students, 5 Sultan Agung University students, 4 Muhammadiyah University students, and 8 Dian Nuswantoro University students, it was found that there was a phenomenon that students had problems with their financial management. In this survey, we took students from 4 universities because during a pandemic like this there are not many students in one university who live in the city of Semarang, so the sampling is focused on students from these four universities because there are relatives and friends who are studying economics at the university.

Based on the results of observations there are some students who still have difficulty in managing finances well. So it can be concluded that the allocation of student spending budgets for needs outside of college exceeds the portion of the distribution of financial expenditures that should be. Another result found the fact that the amount of student expenditure was greater than the amount of income. This is the impact of the budget deficit. The above phenomenon shows that the importance of financial management among students. Students who have healthy financial behavior are indicated by good planning, management, and financial control activities. Good financial management will help students in making short-term and long-term plans, so it is hoped that by implementing this they can make financial prosperity. The main financial source of students comes from pocket money obtained from their parents, in addition to getting pocket money from their parents, not a few students add to their finances by working part-time. The purpose of students doing part-time work is not only to increase finances, but also to reduce the burden on their parents, and to gain experience while sitting in college. The research objective is to analyze the effect of financial knowledge on financial behavior with financial attitudes and self-efficacy as mediating variables.

\section{Literature Review and Hypotheses Development}

\section{Theory of Planned Behavior}

This theory was further developed by Ajzen (1985) into Theory of Planned Behavior (TPB) which is intended to predict individual behavior more specifically. This theory assumes that individual behavior is not only controlled by himself (full control of the individual), but also requires control, namely the availability of resources and opportunities and even certain skills, so it is necessary to add the concept of behavioral control that is perceived to influence intentions and behavior. The theory of planned behavior explains how certain behaviors can be predicted through the determinants of that behavior.

The determinant factors that influence planned behavior include positive or negative attitudes towards target behavior, subjective norms and perceived behavior control. Attitudes toward a behavior are recognized as positive or negative evaluations of the relevant behavior that 
are formed from beliefs about the results that will be received for the behavior (Ajzen, 1991). Subjective norm is a person's perception of a significant reference. Meanwhile, behavioral control is identical to the behavioral model proposed by Fishbein and Ajzen, namely the perceived difficulty of obtaining behavior.

The theory of planned behavior explains control beliefs and behavioral beliefs which are constructs to shape individual behavior. Financial knowledge here can be included in the control belief. Control belief is related to knowledge that is able to direct individuals to make good judgments in taking an action. The theory of planned behavior specifically links beliefs or beliefs with attitudes. Based on this, financial attitudes can be said as evaluations carried out to form a strong attitude in choosing to take an action related to the financial aspect, therefore financial attitudes are connected with the theory of planned behavior.

\section{Cognitive Social Theory}

Social cognitive theory was developed by Bandura (1986), based on the proposition that both social and cognitive processes are central to understanding human motivation, emotion, and action. Selfefficacy theory also known as social cognitive theory, or social learning theory, refers to an individual's belief that he or she is capable of carrying out a task. The higher the self-efficacy, the more confident you are in your ability to succeed (Mukhid, 2009). Cognitive Social Theory, students are more likely to try, persist, and try to succeed in activities and tasks when they have a strong sense of self-efficacy (Bandura, 1986). Self-efficacy refers to the belief that one can achieve and succeed at a given task accompanied by motivation, optimism and belief that one can overcome various life challenges (Bandura, 1986).

There is a strong relationship between the extent to which students have good self-efficacy and personal financial management based on financial literacy skills. Bandura (1986) states that individuals make everyday life decisions based on their perception of their abilities in certain areas. Similarly, students make financial decisions based on their perceived abilities.

In cognitive social theory explains self-efficacy is a construct to shape individual behavior. Cognitive social theory emphasizes that humans are active individuals and use their cognitive potential to describe an event, anticipate something, and choose a series of actions to be taken (Puspita \& Isnalita, 2019). The concept of belief in self-efficacy in social cognitive theory explains the ability of individual knowledge to play a central role in the process of self-regulation (Bandura, 1986). Self-efficacy can affect the choices made and actions taken by individuals related to financial aspects in which the individual feels competent and confident. Self-confidence that influences these choices will determine the experience and promote opportunities for individuals to control life with good financial behavior.

\section{Financial Behavior}

Good financial behavior is the ability of individuals who are able to accumulate and manage assets well (Herd et al., 2012). Financial behavior is a determinant dimension of financial literacy. In fact, financial behavior is one of the most important elements in financial literacy (OECD, 2012). Behavioral finance can be useful for looking at individual decision-making approaches, including cognitive and emotional biases. Behavioral finance makes the premise that various objective and subjective issues affect the decision-making process. With a good financial attitude, a person will be better at making various decisions related to financial management. The indicators used are: a. Types of individual financial planning and budgeting. b. Saving activity. c. Financial management monitoring. d. Evaluation of financial management. e. Investment activities, credit/debt, and bills.

\section{Self-efficacy}

Self-efficacy is part of the social cognitive theory developed by Albert Bandura. Self-efficacy is an individual's belief about his ability to carry out a task or take an action needed to achieve a certain result (Bandura, 1986). Bandura (1986) self-efficacy is defined as a person's beliefs about their own abilities that have an influence on events that affect their lives. Individuals with a high level of 
competence or ability will increase their positive assessment of themselves (Puspita \& Isnalita, 2019). So that the individual can realize their abilities and try to use them appropriately. A high level of self-efficacy is expected to produce benefits for individual well-being, especially physical and mental health, this can affect individual behavior changes (Gecas, 1989).

Confidence related to financial aspects can be explained through individual self-assessment regarding their financial knowledge (Ramalho \& Forte, 2018). So that self-confidence related to financial aspects is defined as an individual's positive attitude towards knowledge and competence related to financial aspects. Individuals can avoid facing difficult financial management decisions if they have not experienced positive things because of a lack of confidence in themselves. Therefore, it is important to consider the impact of self-confidence on financial literacy because it can indicate or reveal a lack of individual confidence in the knowledge possessed making it difficult to make good financial decisions.

\section{Financial Attitude}

Individual attitudes towards finances are an important component in individual financial decision making. Attitudes and preferences are treated as vital components of financial literacy (OECD, 2012). The financial attitudes possessed by individuals will help in determining their attitudes and behavior in financial matters, whether in terms of financial management, personal financial budgeting, or how individuals make decisions about investment to be taken. Aminatuzzahra (2014), individuals who are rational and more confident in terms of financial knowledge have an effect on more profitable financial behavior. Individuals in choosing to behave are basically related to their attitudes, including in managing their finances. Students with better financial attitudes tend to be wiser in their financial behavior when compared to students with poor financial attitudes (Herdjiono \& Damanik, 2016).

Grable and Joo (2004), individual financial attitude is a combination of individual personality characteristics and socioeconomic background that can help in achieving financial success. Therefore, attitudes are related to preferences that can influence behavior. Thus, financial attitudes are considered as an important element of financial literacy, given that individual preferences are determinants of financial behavior (OECD, 2012). The indicators used are: a. Control over personal finances. b. Money security. c. Financial management. d. On Budget. e. Assess personal finances.

\section{Financial Knowledge}

Individual knowledge has an important part in coordinating all aspects of financial literacy in shaping individual financial behavior (Agarwalla et al., 2013). Puspita and Isnalita (2019), financial knowledge is defined as an individual's knowledge of his own financial situation resulting from understanding financial concepts and treating it as a prerequisite for making effective financial decisions. This condition shows that individual financial knowledge is not only limited to understanding the income and expenses that occur, but there are other financial elements that can influence individual decisions in managing their finances.

Potrich et al. (2016), financial knowledge has 2 (two) dimensions of approach, namely: basic financial knowledge and advanced financial knowledge. Basic financial knowledge is an individual's knowledge of basic concepts related to financial composition, including: tax rates, inflation, and the value of money based on time, while advanced financial knowledge is an individual's knowledge of investment instruments, the function of the capital market, and the selection of investments in certain instruments. Knowledge of interest rates, inflation, and risk is a form of advanced financial knowledge that must be possessed by individuals in making a decision. related to finances.

Individuals with inadequate financial knowledge will hinder making the right decisions in managing their finances, both in investment, consumption, and savings activities. Meanwhile, individuals with good financial knowledge will have a stronger perception to make decisions in a wise and responsible way as a result of more adequate learning in the past. Experts also generally agree that financial knowledge appears to have a direct influence on financial behavior in order to benefit oneself (Hilgert et al., 2003). The indicators used are: a. Knowledge of financial 
management/management. b. Knowledge of financial planning. c. Knowledge of expenses and income. d. Basic knowledge of investment. e. Deposit investment knowledge.

\section{Financial Literacy}

Financial knowledge is an integral dimension, but it is not the same as financial literacy (Kartawinata \& Mubaraq, 2018). Financial literacy goes deeper than financial education, so their use of synonyms can cause problems. Huston (2010) argues that financial literacy has two dimensions: understanding, which represents personal financial knowledge from financial education, and use which refers to the management of personal financial knowledge. In this context, the individual can have financial knowledge, but to be considered understanding, he must have the ability and confidence to implement it when making decisions. This shows that financial literacy must reflect the individual's ability to understand financial information and use it skillfully and confidently (Huston 2010) and must be understood as a complex phenomenon consisting of a combination of knowledge, attitudes and behavior (OECD , 2012) that is suitable for use. from a multi-dimensional view to conceptualizing and operationalizing constructs.

Financial literacy can be defined by four variables: financial knowledge, financial attitudes, financial behavior, and financial ability, all of which are correlated with each other and financial knowledge that coordinates attitudes that influence financial management behavior. Individual knowledge has an important part in coordinating all aspects of financial literacy in shaping individual financial behavior. Therefore, many theories focus on aspects of financial literacy on three dimensions, namely: financial knowledge, financial attitudes, and financial behavior (OECD, 2012, Agarwalla et al., 2013).

\section{The Effect of Financial Knowledge on Financial Behavior}

The theory of planned behavior (TPB) explains that individual behavior is shaped by a control concept that is owned by each individual (Ajzen, 1991). The concept of good individual control will direct individuals to behave better. Financial knowledge is a concept of individual control regarding financial aspects owned. High control based on the knowledge possessed by individuals will direct them to consider in conducting financial transactions. These considerations will lead individuals to behave more selectively in managing their finances.

Individuals who have an understanding of financial management will acquire good financial knowledge. Students are individuals with a good level of financial knowledge, because these students experience a learning process related to complex financial aspects. Students' financial knowledge is expected to be able to make selective financial decisions, so that they are able to change their behavior and ability to solve daily financial problems.

Herawati et al. (2018), Tang and Baker (2016), Ramalho and Forte (2018) state that financial knowledge has a positive and significant influence on student financial behavior. Increasing financial literacy is a way to increase empowerment and quality of life. Thus, when students gain more knowledge about the concept of money they will be able to make better financial decisions. H1: Financial knowledge has a positive effect on financial behavior

\section{The Effect of Financial Knowledge on Financial Attitude}

The theory of planned behavior (TPB) explains that the control possessed by an individual directs the individual to have a better attitude. Financial knowledge will lead individuals to use the principles of financial management as a control on the financial condition of the individual. High financial knowledge will give birth to a complex financial outlook, thus encouraging individuals to be more active in evaluating their financial condition. Evaluations of financial condition encourage individuals to have good financial attitudes formed by a belief on the basis of financial knowledge they have.

Students are individuals with very complex learning related to financial aspects, so with this knowledge, students are expected to be able to form positive attitudes towards finance based on their financial knowledge. The positive attitude of students towards the financial aspect is the result 
of the evaluation process of their financial condition. Evaluations of the financial condition of students are based on their financial knowledge, so that the evaluation process is carried out based on the correct concept of financial management.

Tang and Baker (2016) and Garber and Koyama (2016) states that financial knowledge has a positive effect on individual financial attitudes. In his research, it is stated that good financial knowledge in individuals will encourage the formation of individual positive attitudes towards financial attitudes. This attitude is formed on the conceptualization of ideas related to the knowledge possessed.

H2: Financial knowledge has a positive effect on financial attitudes

\section{The Influence of Financial Attitudes on Financial Behavior}

The theory of planned behavior (TPB) explains that attitude is a construct formed from behavioral beliefs. Attitude is a construct that grows on the evaluation process of a condition that fosters confidence in the individual (Ajzen, 1991). Strong beliefs in oneself lead individuals to always behave better based on the beliefs they have. Financial attitude is a process of evaluating the individual's financial condition, thus giving birth to an attitude to use the finances they have. Individuals with a good financial evaluation process will give birth to a wise attitude in carrying out their finances, so that individual financial behavior will be more selective in carrying out financial actions (Herdjiono \& Damanik 2016).

Students are individuals who must be able to evaluate a financial problem, and be able to form ideas in their decisions related to financial aspects. The financial attitude formed by students is a financial decision based on understanding the ideas and feelings that are formed in students as a result of the learning process. Students with an understanding of ideas and awareness related to financial aspects will be able to form a good financial decision, so that the student's financial behavior is positive.

Potrich et al. (2016), Tang and Baker (2016), Garber and Koyama (2016) state that financial attitudes have a positive effect on individual financial behavior so it can be concluded that good financial attitudes will shape good financial behavior in individuals.

H3 : Financial attitude has a positive effect on financial behavior

\section{The Effect of Financial Knowledge on Financial Behavior with Financial Attitude as a Mediation Variable}

The theory of planned behavior explains that control beliefs and behavioral beliefs are constructs to shape individual behavior (Ajzen, 1991). Control beliefs form a strong perception of control in oneself that directs individuals to take a consideration in carrying out a certain action. Behavioral beliefs are constructs that direct individuals to form a strong attitude based on evaluations that occur to direct individuals to consider taking an action. Financial knowledge is an individual's control over his financial condition. Good financial knowledge gives birth to a process of financial evaluations based on a good understanding of financial management. The evaluations carried out form a strong attitude to choose in taking an action related to the financial aspect.

The knowledge of complex financial management in students is expected to give birth to a broad view related to financial aspects, so that students can apply it in their financial condition. The financial attitude formed by students is a financial decision based on understanding the ideas and feelings that are formed in students as a result of the learning process. Individuals with a good financial evaluation process will give birth to a wise attitude in carrying out their finances, so that individual financial behavior will be more selective in carrying out financial actions (Herdjiono \& Damanik 2016).

Garber and Koyama (2016) and Tang and Baker (2016) confirm that good knowledge in individuals is able to form good attitudes based on the results of evaluations carried out, so that these attitudes form a more selective financial behavior.

H4: Financial attitudes can mediate the effect of financial knowledge on financial behavior 


\section{The Effect of Financial Knowledge on Self Efficacy}

Cognitive social theory considers that self-efficacy is a key variable that affects self-regulated learning. Bandura (1986), self-efficacy beliefs are a key factor in the source of human action (human agency). The concept of self-confidence in social cognitive theory explains the ability of individual knowledge to play a role in the process of self-regulation Bandura (1986). Self-efficacy as an individual's belief about the ability of his knowledge has an influence on events that affect his life. This belief is based on an individual's feeling that they have the cognitive abilities, motivation, and resources needed to complete a task (Bandura, 1986).

Students are individuals with a complex level of financial knowledge, good financial knowledge creates self-confidence within the individual. Individual self-confidence is an important part of self-efficacy that encourages individuals to make a decision (Flores, 2014).

Herawati et al. (2018), Puspita and Isnalita (2019) and Ramalho and Forte (2018) state that financial knowledge has a positive effect on self-efficacy, the higher the financial knowledge, the higher the self-efficacy.

H5: Financial knowledge has a positive effect on self-efficacy

\section{The Effect of Self-efficacy on Financial Behavior}

Bandura social cognitive theory, self-efficacy beliefs influence individuals' choices in making and carrying out the actions they pursue. Self-efficacy beliefs are a key source of human action (human agency), "what people think, believe, and feel influences how they behave" (Bandura 1986). In the basic social cognitive concept, self-efficacy refers to a person's level of confidence in his or her ability to perform behavior successfully. High self-efficacy helps create a feeling of calm in carrying out difficult tasks and activities (Mukhid, 2009). Conversely, people who doubt their abilities, they can believe that something is more difficult than it really is.

Students are individuals who must have high self-efficacy, thus creating a feeling of calm in the face of a job that is considered difficult. Self-efficacy is the belief that one can master the situation and produce positive results (Herawati et al., 2018). A higher sense of self-efficacy will have an impact on greater effort, persistence, and resilience (Seifert, 2004). Based on this, students with high self-efficacy are considered capable of forming positive behavior towards finances when faced with choices and actions taken related to financial aspects.

Herawati et al. (2018) and Ramalho and Forte (2018) show that self-efficacy can foster selfconfidence in their financial management capacity, so that it can have a real influence on their personal financial results.

H6: Self-efficacy has a positive effect on financial behavior

\section{The Effect of Financial Knowledge on Financial Behavior with Self-efficacy as a Mediation Variable}

In cognitive social theory explains self-efficacy is a construct to shape individual behavior (Bandura, 1986). Cognitive social theory emphasizes that humans are active individuals and use their cognitive potential to describe an event, anticipate something, and choose a series of actions to be taken (Puspita \& Isnalita, 2019). Based on this, self-efficacy is considered to be able to influence the choices made and actions taken by individuals related to financial aspects where the individual feels competent and confident. Self-confidence that influences these choices will determine the experience and promote opportunities for individuals to control life with good financial behavior.

Students are individuals with learning related to complex financial aspects, with this knowledge students are expected to have high self-efficacy. positive. Puspita and Isnalita (2019) and Ramalho and Forte (2018) state that self-confidence mediates the effect of financial knowledge on financial behavior. This means that the higher the individual's financial knowledge will form high self-confidence, so that confidence will form good financial behavior.

H7: Self-efficacy can mediate the effect of financial knowledge on financial behavior. 


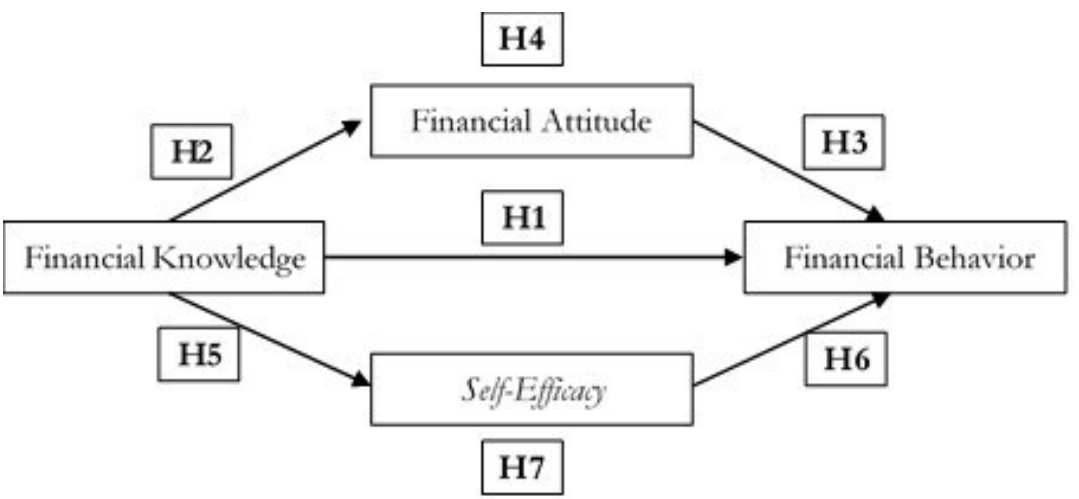

Figure 1. Conceptual Framework

\section{Research Methods}

\section{Population and Sample}

The population of this research is that all students in Semarang are unknown. To determine the number of samples based on the Schmeiser and Seligman (2013) formula:

Information :

$$
n=\frac{Z^{2}}{4(M o E)^{2}}
$$

$\mathrm{n}=$ Sample size

$Z=1.96$ score at a certain level of significance (degree of confidence is determined $95 \%$ ) Moe= Margin of error, the maximum error rate is $10 \%$

$$
\begin{gathered}
n=\frac{(1,96)^{2}}{4(0,1)^{2}} \\
n=96,04
\end{gathered}
$$

So the number of respondents to 96 people. The sample selection method is purposive sampling where the determination of the sample is determined based on its characteristics, namely: students

\begin{tabular}{|c|c|c|c|}
\hline No & Variable & Variable Definition & $\begin{array}{l}\text { Indicator } \\
\end{array}$ \\
\hline 1. & $\begin{array}{l}\text { Financial } \\
\text { Behavior }\end{array}$ & $\begin{array}{l}\text { Financial behavior is the ability of } \\
\text { individuals who are able to accumulate } \\
\text { and manage assets well }\end{array}$ & $\begin{array}{l}\text { a. Types of individual financial planning and budgeting } \\
\text { b. Saving activity } \\
\text { c. Financial management monitoring. } \\
\text { d. Evaluation of financial management. } \\
\text { e. Investment activities, credit/debt, and bills }\end{array}$ \\
\hline 2. & $\begin{array}{l}\text { Financial } \\
\text { Knowledge }\end{array}$ & $\begin{array}{l}\text { Financial knowledge is an individual's } \\
\text { knowledge of his own financial } \\
\text { situation resulting from understanding } \\
\text { financial concepts and treating them as } \\
\text { a prerequisite for making effective } \\
\text { financial decisions }\end{array}$ & $\begin{array}{l}\text { a. Knowledge of financial management/management. } \\
\text { b. Knowledge of financial planning. } \\
\text { c. Knowledge of expenses and income. } \\
\text { d. Basic knowledge of investment. } \\
\text { e. Deposit investment knowledge. }\end{array}$ \\
\hline 3. & $\begin{array}{l}\text { Financial } \\
\text { Attitude }\end{array}$ & $\begin{array}{l}\text { Financial attitude is an individual who } \\
\text { is rational and more confident in terms } \\
\text { of financial knowledge that affects } \\
\text { more profitable financial behavior }\end{array}$ & $\begin{array}{l}\text { a. Control over personal finances. } \\
\text { b. Money security. } \\
\text { c. Financial management } \\
\text { d. On Budget } \\
\text { e. Assess personal finances. }\end{array}$ \\
\hline 4. & Self Efficacy & $\begin{array}{l}\text { Self-efficacy is a person's beliefs about } \\
\text { their own abilities that have an } \\
\text { influence on events that affect their } \\
\text { lives }\end{array}$ & $\begin{array}{l}\text { a. Trust in managing finances } \\
\text { b. Trust to save } \\
\text { c. Trust in financial services } \\
\text { d. Confident in taking financial risks } \\
\text { e. Not sure about future finances }\end{array}$ \\
\hline
\end{tabular}
have taken courses in financial management and intermediate financial accounting.

Table 1. Variables and Operational Definitions 


\section{Data analysis technique}

The model used in this research is a model of causality or the relationship of influence between research variables. This study uses the method of analyzing data obtained from questionnaires using the Warp PLS software version 5.0.

\section{Hypothesis testing}

Hypotheses were tested at a significant level of 0.1 ( $90 \%$ confidence level). To find out the decision making of the hypothesis test, it is done by comparing the level of significance and alpha (0.1), with the following conditions: If significant $<0.1$ means $\mathrm{Ha}$ is accepted (the independent variable partially has a significant effect on the dependent variable) and if otherwise $\mathrm{Ha}$ is rejected (the independent variable partially has no significant effect on the dependent variable).

Table 2. Coefficient of Determination Interpretation Guide

\begin{tabular}{ll}
\hline Statement & Information \\
\hline $4 \%$ & Very low influence \\
$5 \%-16 \%$ & Low but sure influence \\
$17 \%-49 \%$ & Significant influence \\
$50 \%-80 \%$ & High or strong influence \\
$>80 \%$ & Very high influence \\
\hline
\end{tabular}

Source: Processed Data, 2021

\section{Results and Discussion}

\section{Convergent Validity}

In this study, the measurement of the outer model is used with the loading factor value of each indicator. The reflective measure is said to be high and is highly recommended if it has a correlation of more than 0.7 with the construct to be measured, however the outer loading factor value $>0.50$ is considered sufficient.

Table 3. Combined Loading and Cross Loading Results

\begin{tabular}{lccccc}
\hline & PN & S & SE & PR & p-value \\
\hline PN1 & 0.781 & -0.005 & -0.293 & 0.312 & $<0.001$ \\
PN2 & 0.662 & -0.102 & 0.088 & -0.020 & $<0.001$ \\
PN3 & 0.649 & -0.099 & 0.216 & -0.039 & $<0.001$ \\
PN4 & 0.781 & 0.130 & -0.199 & 0.109 & $<0.001$ \\
PN5 & 0.733 & 0.047 & 0.254 & -0.396 & $<0.001$ \\
S1 & -0.147 & 0.710 & -0.217 & 0.156 & $<0.001$ \\
S2 & 0.100 & 0.773 & -0.079 & -0.102 & $<0.001$ \\
S3 & -0.196 & 0.667 & 0.035 & 0.179 & $<0.001$ \\
S4 & 0.112 & 0.776 & 0.088 & -0.155 & $<0.001$ \\
S5 & 0.102 & 0.690 & 0.180 & -0.044 & $<0.001$ \\
SE1 & -0.112 & -0.096 & 0.787 & 0.135 & $<0.001$ \\
SE2 & 0.087 & 0.145 & 0.734 & 0.030 & $<0.001$ \\
SE3 & 0.036 & 0.163 & 0.803 & -0.218 & $<0.001$ \\
SE4 & 0.074 & -0.091 & 0.698 & -0.130 & $<0.001$ \\
SE5 & -0.106 & -0.188 & 0.524 & 0.261 & $<0.001$ \\
PR1 & -0.249 & -0.042 & 0.069 & 0.655 & $<0.001$ \\
PR2 & 0.009 & -0.060 & 0.051 & 0.728 & $<0.001$ \\
PR3 & 0.413 & 0.164 & -0.125 & 0.626 & $<0.001$ \\
PR4 & 0.162 & 0.056 & 0.184 & 0.670 & $<0.001$ \\
PR5 & -0.295 & -0.097 & -0.178 & 0.714 & $<0.001$ \\
\hline Source: Processed Data 2021 & & &
\end{tabular}

The combined loading and cross loading test results show that all indicators have a cross loading value above 0.5 with a $\mathrm{p}$-value of $<0.001$. Therefore, all indicators measuring the construct have met convergent validity or are said to be valid. 


\section{Average Variance External}

The validity of the variables was tested with the Average variances extracted (AVE) value. If the AVE value $>0.5$, then the variables used in the study are declared valid.

Tabel 4. Average Variance Extracted (AVE)

\begin{tabular}{cccc}
\hline PN & S & SE & PR \\
\hline 0,523 & 0,525 & 0,513 & 0,549 \\
\hline
\end{tabular}

Source: Processed Data, 2021

Table 4 shows that the average variance extracted (AVE) value for the financial knowledge variable construct $(\mathrm{PN})$, is known to be 0.523 , the AVE value for the financial attitude variable is known to be 0.525 , the AVE value of the self-efficacy variable is known to be 0.513 and the AVE value of the financial behavior variable is known. of 0.549 . Because all constructs have an average variance extracted (AVE) value greater than 0.5.

\section{Composite Reliability}

The reliability test was carried out by measuring the composite reliability value. The latent variable can be said to have good reliability if the composite reliability value is more than 0.7 . If this value is met, all items used in the measurement of a construct are declared reliable. The output results of composite reliability can be seen in table 4.10 below:

Tabel 5. Composite Reliability Results

\begin{tabular}{cccc}
\hline PN & S & SE & PR \\
\hline 0,845 & 0,846 & 0,838 & 0,857 \\
\hline
\end{tabular}

Source: Processed Data, 2021

Table 5 shows that the composite reliability value for the financial knowledge variable (PN) is known to be 0.845 , the composite reliability value for the financial attitude variable is 0.846 , the composite reliability value for the self-efficacy variable is known to be 0.838 and the composite reliability value for the financial behavior variable is 0.857 . These results indicate that all variables have a composite reliability value greater than 0.70 . Thus the model in this study has met composite reliability. In addition to looking at the value of composite reliability, reliability testing is also done by looking at Cronbach's alpha.

Tabel 6. Cronbach Alpha Results

\begin{tabular}{cccc}
\hline PN & S & SE & PR \\
\hline 0,770 & 0,772 & 0,755 & 0,789 \\
\hline \multicolumn{2}{l}{ Source: Processed Data, } & 2021
\end{tabular}

Table 6 shows that the cronbach alpha value for the financial knowledge variable (PN) is known to be 0.770 , the cronbach alpha value for the financial attitude variable is 0.772 , the cronbach alpha value for the self-efficacy variable is 0.755 and the cronbach alpha value for the financial behavior variable is 0.789 . These results indicate that all variables have a Cronbach alpha value greater than 0.70 . Thus these results indicate the consistency and stability of the instrument used is very high and it can be concluded that the reliability of the instrument is met.

\section{Coefficient of Determination}

In assessing the model with PLS, it begins by looking at the R-square for each dependent latent variable. R-square estimation can be shown in the Table 7. It shows the results of testing the structural model where the R-square coefficient value for the financial attitude variable is 0.081 which means that financial knowledge contributes $8.1 \%$ influence on financial attitudes. 
Meanwhile, the R-square coefficient for the self-efficacy variable is 0.058 , which means that financial knowledge contributes 5.8\% to self-efficacy. The R-square coefficient for the financial behavior variable is 0.440 , which means that financial knowledge, financial attitudes and selfefficacy contribute $44 \%$ to self-efficacy, while the remaining $56 \%$ is influenced by other exogenous variables not used in this study.

Table 7. Value of R-square Coefficients

\begin{tabular}{cccc}
\hline PN & S & SE & PR \\
\hline & 0,081 & 0,058 & 0,440 \\
\hline
\end{tabular}

Source: Processed Data, 2021

\section{Path coefficient and P-values}

Path coefficient and P-values are hypothesis testing that shows the relationship between each construct. The results of the calculation of the Path coefficient and P-values, namely:

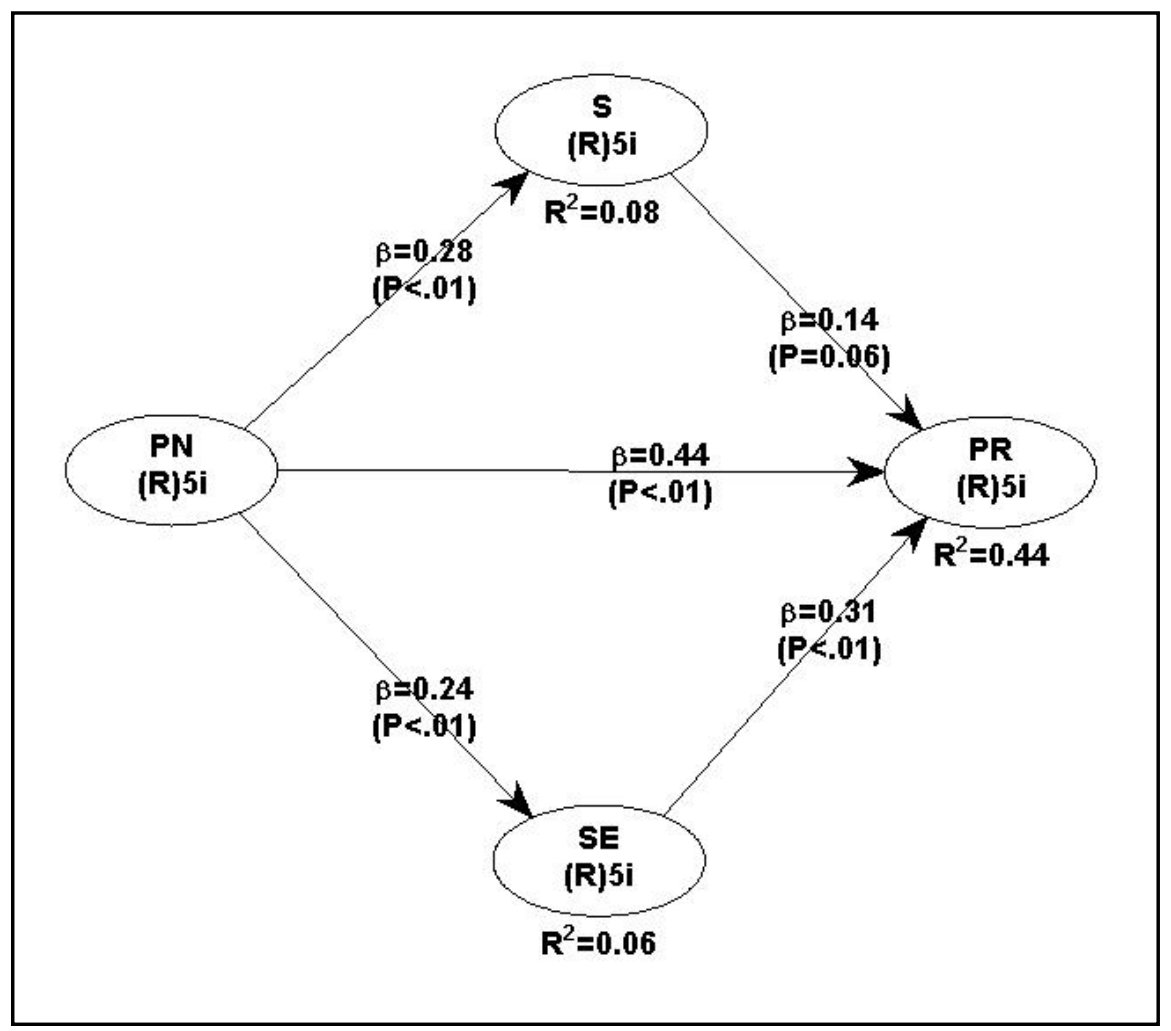

Figure 2. Path coefficient and P-values

\section{Hypothesis Test}

Tabel 9. Hypothesis Test

\begin{tabular}{llll}
\hline Hypothesis & Path Coeficient & P-Value & Information \\
\hline Direct Influence & & & \\
PN $\rightarrow$ S & 0,284 & 0,001 & Significant Influence \\
PN $\rightarrow$ SE & 0,242 & 0,005 & Significant Influence \\
PN $\rightarrow$ PR & 0,436 & $<0,001$ & Significant Influence \\
$\mathrm{S} \rightarrow$ PR & 0,144 & 0,065 & Significant Influence \\
SE $\rightarrow$ PR & 0,309 & $<0,001$ & Significant Influence \\
Indirect Influence & & & \\
PN $\rightarrow$ S $\rightarrow$ PR & 0,116 & 0,112 & S does not mediate \\
PN $\rightarrow$ SE $\rightarrow$ PR & 0,065 & 0,112 & SE does not mediate \\
\hline S
\end{tabular}

Source: Processed Data, 2021 


\section{Hypothesis testing 1}

Path coefficient test results and p-value on testing the direct influence of financial knowledge on financial attitudes obtained path coefficient value of 0.284 and p-value of 0.001 smaller than 0.1 $(<10 \%)$, then $\mathrm{H} 1$ is accepted, meaning that financial knowledge has a direct effect positively and significantly on the financial attitudes of students in the city of Semarang. Individuals who have an understanding of financial management will acquire good financial knowledge. Students are individuals with a good level of financial knowledge, because these students experience a learning process related to complex financial aspects. Students' financial knowledge is expected to be able to make selective financial decisions, so that they are able to change their behavior and ability to solve everyday financial problems. The results of the study were supported by Herawati et al. (2018), Tang and Baker (2016), Ramalho and Forte (2018) state that financial knowledge has a positive and significant influence on student financial behavior. Increasing financial literacy is a way to increase empowerment and quality of life. Thus, when students gain more knowledge about the concept of money they will be able to make better financial decisions.

\section{Hypothesis testing 2}

The results of the path coefficient test and p-value on testing the direct influence of financial knowledge on self-efficacy obtained the path coefficient value of 0.242 and the p-value of 0.005 smaller than $0.1(<10 \%)$, then $\mathrm{H} 2$ is accepted, meaning that financial knowledge has a direct effect positively and significantly on the self-efficacy of students in the city of Semarang. Students are individuals with very complex learning related to financial aspects, so with this knowledge, students are expected to be able to form positive attitudes towards finance based on their financial knowledge. The positive attitude of students towards the financial aspect is the result of the evaluation process of their financial condition. Evaluations of the financial condition of students are based on their financial knowledge, so that the evaluation process is carried out based on the correct concept of financial management. Good financial knowledge in individuals will encourage the formation of positive individual attitudes towards financial attitudes. This attitude is formed on the conceptualization of ideas related to the knowledge possessed. The results of this study are supported by Tang and Baker (2016) and Garber and Koyama (2016), that financial knowledge has a positive effect on individual financial attitudes.

\section{Hypothesis testing 3}

Path coefficient test results and p-value on testing the direct influence of financial knowledge on financial behavior obtained path coefficient value of 0.436 and $p$-value of $<0.001$ smaller than 0.1 $(<10 \%)$, then $\mathrm{H} 3$ is accepted, meaning that financial knowledge has an effect directly positively and significantly on the financial behavior of students in the city of Semarang. Students are individuals who must be able to evaluate a financial problem, and be able to form ideas in their decisions related to financial aspects. The financial attitude formed by students is a financial decision based on understanding the ideas and feelings that are formed in students as a result of the learning process. Students with an understanding of ideas and awareness related to financial aspects will be able to form a good financial decision, so that the student's financial behavior is positive. Good financial attitude will form good financial behavior in individuals. The results of this study are supported by Aminatuzzahra (2014), Potrich et al. (2016), Tang and Baker (2016), Garber and Koyama (2016) that financial attitudes have a positive effect on individual financial behavior.

\section{Hypothesis testing 4}

The results of the path coefficient test and p-value on testing the direct influence of financial attitudes on financial behavior obtained path coefficient values of 0.144 and p-values of 0.065 which are smaller than $0.1(<10 \%)$, then $\mathrm{H} 4$ is accepted, meaning that financial attitudes have a direct effect. positively and significantly on the financial behavior of students in the city of Semarang. The knowledge of complex financial management in students is expected to give birth 
to a broad view related to financial aspects, so that students can apply it in their financial condition. The financial attitude formed by students is a financial decision based on understanding the ideas and feelings that are formed in students as a result of the learning process. Individuals with a good financial evaluation process will give birth to a wise attitude in carrying out their finances, so that individual financial behavior will be more selective in carrying out financial actions (Herdjiono \& Damanik 2016). The results of this study are supported by Aminatuzzahra (2014), Garber and Koyama (2016) and Tang and Baker (2016) which confirm that good knowledge in individuals is able to form good attitudes based on the results of evaluations carried out, so that these attitudes form a more selective financial behavior.

\section{Hypothesis testing 5}

The results of the path coefficient test and p-value on testing the direct influence of self-efficacy on financial behavior obtained a path coefficient value of 0.309 and a $\mathrm{p}$-value of $<0.001$ smaller than $0.1(<10 \%)$, then $\mathrm{H} 5$ is accepted, meaning that self-efficacy has an effect directly positively and significantly on the financial behavior of students in the city of Semarang. Students are individuals with a complex level of financial knowledge, good financial knowledge creates selfconfidence within the individual. Individual self-confidence is an important part of self-efficacy that encourages individuals to make a decision (Flores, 2014). The higher the financial knowledge, the higher the self-efficacy. The results of Herawati et al. (2018), Puspita and Isnalita (2019) and Ramalho and Forte (2018) state that financial knowledge has a positive effect on self-efficacy.

\section{Hypothesis testing 6}

The results of the path coefficient test and p-value on testing the indirect effect of financial knowledge on financial behavior through financial attitudes as a mediator obtained a path coefficient value of 0.116 and a p-value of 0.112 which is greater than $0.1(>10 \%)$, then $\mathrm{H} 6$ rejected means that financial attitudes do not mediate the effect of financial knowledge on student financial behavior in the city of Semarang. Students are individuals who must have high self-efficacy, thus creating a feeling of calm in the face of a job that is considered difficult. Self-efficacy is the belief that one can master the situation and produce positive results (Herawati et al., 2018). A higher sense of self-efficacy will have an impact on greater effort, persistence, and resilience (Seiferd, 2004). Based on this, students with high self-efficacy are considered capable of forming positive behavior towards finances when faced with choices and actions taken related to financial aspects. The results of this study were supported by Herawati et al. (2018) and Ramalho and Forte (2018) which show that self-efficacy can foster self-confidence in their financial management capacity, so that it can have a real influence on their personal financial results.

\section{Hypothesis testing 7}

The results of the path coefficient test and p-value on testing the indirect effect of financial knowledge on financial behavior through self-efficacy as a mediator obtained a path coefficient value of 0.065 and a p-value of 0.112 which is greater than $0.1(>10 \%)$, then $\mathrm{H} 7$ rejected means that self-efficacy does not mediate the effect of financial knowledge on student financial behavior in the city of Semarang. Students are individuals with learning related to complex financial aspects, with this knowledge students are expected to have high self-efficacy. High self-efficacy is expected to be able to face choices and actions taken related to financial aspects, so as to be able to shape financial behavior that positive. The results of this study are supported by Puspita and Isnalita (2019) and Ramalho and Forte (2018) that self-confidence mediates the effect of financial knowledge on financial behavior.

\section{Implication and Conclusion}

Financial knowledge has a positive and significant direct effect on financial attitudes, self-efficacy and financial behavior of students in Semarang City, so that the proposed hypothesis can be accepted. Financial attitudes and self-efficacy have a direct and positive effect on the financial 
behavior of students in Semarang City, so that the proposed hypothesis can be accepted. Financial attitudes and self-efficacy do not mediate the effect of financial knowledge on financial behavior of students in Semarang City, so the proposed hypothesis can be rejected.

The limitations of the research are: the sample of this research is students, where during the pandemic students are not on campus, so that the distribution of questionnaires cannot be done directly and these results show that the variables of financial attitude and self-efficacy are not able to mediate the effect of financial knowledge on financial behavior of students in Semarang city.

The suggestion is to increase knowledge about finance, students can improve financial literacy through books, the internet or attend trainings on finance. For future research, it is expected to use the online questionnaire distribution method so that data collection from the questionnaire can be carried out efficiently.

\section{References}

Agarwalla, S. K., Barua, S. K., Jacob, J., and Varma, J.R. (2013). Financial Literacy Among Working Young in Urban India. World Development, 67, 101-109.

Ajzen, I. (1985). From Intentions to Actions: A Theory of Planned Behavior. Berlin Heidelberg: SpringerVerlag.

Ajzen, I. (1991). The Theory of Planned Behavior.Organizational Behavior and Human Decision Processes, 50: 179-211.

Aminatuzzahra. (2014). Persepsi Pengaruh Pengetahuan Keuangan, Sikap Keuangan, Sosial Demografi Terhadap Perilaku Keuangan Dalam Pengambilan Keputusan Investasi Individu. Jurnal Bisnis Strategi, 23(2), 70- 96.

Atkinson, A., and Messy, F.A. (2012). Measuring Financial Literacy: Result of the OECD INFE Pilot Study. OECD Working Paper on Finance, Insurance and Private Pension, No 15. https://doi.org/10.1787/5k9csfs90fr4-en

Bandura, A. (1986). Social Foundations of Thought and Action: Eaglewood Cliffs, NJ: Prentice-Hall.

Adeline D.D., Rohwedder, S., and Willis, R. (2008). Preparation for Retirement, Financial Literacy and Cognitive Resources. Working Papers wp190, University of Michigan, Michigan Retirement Research Center.

Flores, C. (2014). First generation college student financial literacy: Impact of self-efficacy and behavior. Washington: Washington State University.

Garber, G., and Koyama, S.M. (2016). Policy-effective Financial Knowledge and Attitude Factors. Working Papers Series 430, Central Bank of Brazil, Research Department.

Gecas, V. (1989). The Social Psychology of Self-Efficacy. Annual Review of Sociology Annu. Rev. Sociol. 15.(1). 291-316. DOI:10.1146/annurev.so.15.080189.001451

Grable, J.E., and Joo, S.H. (2004). Environmental and Biophysical Factors Associated With Financial Risk Tolerance. Journal of Financial Counseling and Planning, 15(1), 73-82

Hadar, L., Sood, S., and Fox, C. R. (2013). Subjective knowledge in consumer financial decisions. Journal of Marketing Research, 50(3), 303-316.

Herawati, N.T., Candiasa, I.M., Yadnyana, I.K., and Suharsono. N. (2018). Pengaruh Kualitas Pembelajaran Keuangan dan Literasi Keuangan Terhadap Financial Self Efficacy Mahasiswa Akuntansi. Jurnal Pendidikan Ekonomi, Manajemen Dan Kenangan. 2(2). 115-128. DOI: http://dx.doi.org/10.26740/jpeka.v2n2.p115-128

Herd, P., Holden, K., and Su, Y. T. (2012). The Links Between Early-Life Cognition and Schooling and Late-Life Financial Knowledge. Journal of Consumer Affairs,46(3), 411-435. 
Herdjiono, I., and Damanik, L.A. (2016). Pengaruh Financial Attitude, Financial Knowledge, Parental Income Terhadap Financial Management Behavior. Jurnal Manajemen Teori dan Terapan. 9(3), 226-241

Hilgert, M.A., Hogarth, J.M., and Beverly, S.G. (2003). Household Financial Management: The Connection Between Knowledge and Behaviour. Federal Reserve Bulletin, 89, 309-322.

Huang, J., Nam, Y. and Sherraden, M. S. (2013). Financial Knowledge and Child Development Account Policy: A Test of Financial Capability. The Journal of Consumer Affairs, 47(1), 1-26.

Huston, S. J. (2010). Measuring Financial Literacy. The Journal of Consumer Affairs, 44(2). 296-316

Kartawinata, B.R., and Mubaraq, M.I. (2018). Pengaruh Kompetensi Keuangan Terhadap Literasi Keuangan Bagi Wanita di Makassar. Jurnal Kajian Pendidikan Ekonomi dan Ilmu Ekonomi, 2(2). $87-100$

Lusardi., A., and Mitchell., O. S. (2013). The Economic Importance of Financial Literacy: Theory and Evidence. NBER Working Paper, No. 18952.

Mukhid, A. (2009). Self Efficacy: Perspektif Teori Kognitif Sosial dan Implikasinya terhadap Pendidikan. Jurnal Tadrîs, 4(1), 106-122.

Novitasani., L., and Handoyono, P. (2014). Perubahan Gaya Hidup Konsumtif Pada Mahasiswa Urban Di UNESA. Paradigma, 2(3), 1-7.

OECD. (2012). OECD/INFE high-level principles on national strategies for financial education. OECD Publishing.

Puspita, G., and Isnalita, I. (2019). Financial Literacy: Pengetahuan, Kepercayaan Diri dan Perilaku Keuangan Mahasiswa Akuntansi. Owner: Riset dan Jurnal Akuntansi, 3(2), 117-128.

Potrich, A.C.G., Vieira, K.M., and Mendes-Da-Silva, W. (2016). Development of A Financial Literacy Modal for University Students. Management Research Review, 3(39), 356-379.

Ramalho, T. B., and Forte, D. (2018). Financial literacy in Brazil -Do knowledge and selfconfidence relate with behavior? RAUSP Management Journal, 54(1), 77-95. https://doi.org/10.1108/rausp-04-2018-0008

Schmeiser, M. D., and Seligman, J. S. (2013). Using the right yardstick: Assessing financial literacy measures by way of financial well being. Journal of Consumer Affairs, 47(2), 243-262.

Seifert, T. (2004). Understanding student motivation. Educational Research, 46(2), 137-149.

Tang, N., and Baker, A. (2016). Self-esteem, financial knowledge and financial behavior. Journal of Economic Psychologi, 54, 164-176.

Xiao, J. J., Chen, C., and Sun, L. (2015). Age differences in consumer financial capability International Journal of Consumer Studies, 39(4), 387-395. 